\title{
Central Asian Regionalism or Central Asian Order? Some Reflections
}

\author{
Filippo Costa Buranelli \\ Lecturer in International Relations, School of International Relations, \\ University of St Andrews, St Andrews, Scotland, UK \\ fcb7@st-andrews.ac.uk
}

\begin{abstract}
This article reflects on how the concept of regionalism has been used to explain and interpret Central Asian politics since independence. It argues that regionalism, often a norm-laden analytical category based on Eurocentric assumptions, tends to paint the region as "failed" and regional states as incapable of institutionalizing multilateral relations. In its place, the article suggests the concept of order, which is more neutral and-through its focus on the operation of sovereignty, diplomacy, international law, authoritarianism, and great power management-is able to incorporate elements of both the conflict and cooperation that have marked the region's politics since 1991.
\end{abstract}

\section{Keywords}

Central Asia - regionalism - order - theory - institutions - interdisciplinarity

This paper offers reflections on discourses of regionalism in Central Asia, which have been revamped in both the academic and policy spheres since Shavkat Mirziyoyev's election as President of Uzbekistan in late 2016, which led to a thaw in relations between the Central Asian republics. Some commentators have gone so far as to claim that "a new wind of regionalism has swept across Central Asia"1 in the past few years. The thoughts provided here link discourses of regionalism in Central Asia with a wider, overarching trend:

1 Svante E. Cornell and S. Frederick Starr, Modernization and Regional Cooperation in Central Asia: A New Spring? (Washington, DC: Central Asia-Caucus Institute \& Silk Road Studies 
the transformation-if not the slow demise-of the liberal international order, which is being accelerated by increasing great-power competition, the United States' progressive disengagement from its previous position as "orderprovider" (although this may change with the Biden administration), and the COVID-19 pandemic. This analysis builds on a thorough and lively discussion during the workshop "Regionalisms, Neighbourhoods and the Contours of Post-Liberal International Order: Central Asia in the Limelight," held in Dushanbe, Tajikistan, in April 2019. There, new perspectives on Eurasianand, more specifically, Central Asian-politics were debated, pondered, and presented to a public of policymakers, academics, and students of international politics.

Below, consciously writing in a (self-)reflexive style rather than in one that is more canonically research-driven, I outline my contribution to the abovementioned set of new perspectives. In sum, I argue that debates about Central Asian regionalism - in focusing on the failures of regionalism in the region rather than considering other forms of politics there-create an incomplete view of Central Asian international relations, and one that is often framed in negative terms of inability and failure. I further suggest that the notion of regional order should be preferred to that of regionalism, at least for now. "Order" is understood here as a relatively stable and predictable set of relations between social actors that makes it possible for the basic goals of a given social context to be achieved by implementing rules and institutions that enable and protect common interests. By "social actors," I mean states as represented by officials. This paper therefore discusses a regional international order in Central Asia-an order primarily made by and for states. ${ }^{2}$

The argument will be explicated as follows. In the next section, I will elaborate on discourses of regionalism in Central Asia, highlighting their specific characteristics and the different ways in which regionalism is used as an analytical category with specific understandings and expectations of regional politics. Next, I will introduce the reader to the concept of order, discussing its constituent parts and how it differs from regionalism. After that, I will illustrate how Central Asia-which does not necessarily follow regionalist logics of cooperation, integration, and spill-over from below — can be considered an example of a regional order on the basis of specific rules, norms, and institutions. In the concluding section, I recap the argument, propose directions for further research, reflect on the limitations of the present work, and situate

Program, 2018), https://isdp.eu/content/uploads/2018/11/Modernization-and-Regional -Cooperation-in-Central-Asia-Print-V-FINAL-wCover.pdf, 5 .

2 I will elaborate more on the choice of this state-centric position and its obvious limitations in the conclusion. 
the analysis in the broader context of the transformations of the international liberal order.

\section{Regionalism and Central Asia}

In my Dushanbe presentation, entitled "International Society and Central Asia: The Brotherly Republics?", I summarized the Western literature on regionalism in Central Asia, finding broad-although not exclusive-consensus that regionalism in the region has been unproductive and limited, while the region itself is seen as plagued by mistrust, non-cooperation, underlying conflict, and disagreements.

In particular, a multitude of scholars have discussed specific "symptoms" that explain the very limited success of coordinated multilateralism in the region. ${ }^{3}$ It is not by chance that I use a medical term; it echoes Martin Spechler's seminal article that "diagnosed" Central Asia as "pathologically noncooperative." ${ }^{4}$ Several authors have vehemently denial the ontological validity of Central Asia's regionalism, using words such as "impossible,"5 "virtual," 6 a "failure,"7 or a "gloomy picture"8_or, more recently, arguing that Central Asia is "the region that isn't," thus negating the existence not just of regionalism, but of Central Asia itself. Central Asia is, in other words, either "a region without regionalism" or a "non-region" — what Martha Brill Olcott termed a

3 Kathleen Collins, "Economic and Security Regionalism among Patrimonial Authoritarian Regimes: The Case of Central Asia," Europe-Asia Studies 61, no. 2 (2009): 249-281, https://doi .org/10.108o/og668130802630854; Paul Kubicek, "Regionalism, Nationalism and Realpolitik in Central Asia," Europe-Asia Studies 49, no. 4 (1997): 637-655; Roy Allison, "Regionalism, Regional Structures and Security Management in Central Asia," International Affairs 8o, no. 3 (2004): 463-483; Annette Bohr, "Regionalism in Central Asia: New Geopolitics, Old Regional Order," International Affairs 8o, no. 3 (2004): 485-502.

4 Martin Spechler, "Regional Non-Cooperation in Central Asia: A Pathology," in Economic Developments and Reforms in Cooperation Partner Countries: The Interrelationship Between Regional Economic Cooperation, Security and Stability (Bucharest: NATO, 2001).

5 Annette Bohr, "Regional Cooperation in Central Asia: Mission Impossible?" Helsinki Monitor 14, no. 3 (2003): 254-268, https://doi.org/10.1163/157181403322684735.

6 Roy Allison, "Virtual Regionalism, Regional Structures and Regime Security in Central Asia," Central Asian Survey 27, no 2 (2008): 185-202, https://doi.org/10.108o/o2634930802355121.

7 Damian Rosset and David Svarin, "The Constraints of the Past and the Failure of Central Asian Regionalism, 1991-2004," Region 3, no. 2 (2014): 245-266, doi: 10.1353/reg.2014.oo11.

8 Cornell and Starr, Modernization and Regional Cooperation, 7.

9 Sebastian Krapohl and Alexandra Vasileva-Dienes, "The Region that Isn't: China, Russia and the Failure of Regional Integration in Central Asia," Asia Europe Journal 18, no. 3 (2019), doi:10.1007/s10308-019-00548-o. 
"myth"10_ because it does not feature regionalism. For Cornell and Starr, "until recently, regional cooperation among Central Asian states has left much to be desired. Little wonder, then, that [...] the very existence of a Central Asian region has come to be questioned."11

Moving from medical to religious metaphors, some contemporary analyses of how Central Asian states have navigated the CoviD-19 pandemic have argued that "a coordinated region-wide response would have been nothing short of a miracle given the lack of an institutional framework for responding to a global health crisis." ${ }^{12}$

Returning to the metaphor of medicine-what are the symptoms of the very limited success of coordinated multilateralism in the region and how have they impacted regionalism in Central Asia? The brief outline below is not intended to be an in-depth analysis of all possible variables that have hampered regional cooperation in Central Asia, but rather to provide a general overview of the main arguments advanced by the literature.

First, the Central Asian governments' neo-patrimonial nature does not allow for an integrated economic, political, and security system at the regional level. ${ }^{13}$ Since leaders worry that pooling sovereignty and diminishing the significance of borders to facilitate flows of goods and people might have a detrimental impact on their control of strategic economic resources, incentives for deep cooperation to create a regional area of free (or even less controlled) movement are out of the question.

Second, regime preservation is of paramount importance for neopatrimonial rulers. ${ }^{14}$ This prompts them to rule out any cooperation with states deemed not to be fully stable or fully able to control violent segments of their societies, as such cooperation might undermine the ruling elite's security. Security aimed at regime preservation may become so heightened that the three evils of extremism, separatism, and terrorism become an issue even during basic coordination with neighboring states over the movement of goods, the opening and closure of border checkpoints, and information-sharing with respect to common threats. Indeed, this reality plagued Uzbekistan and its neighbors during the late 200os.

\footnotetext{
10 Martha B. Olcott, “The Myth of 'Tsentral'naia Aziia," Orbis 38, no. 4 (1994): 549-565, https://doi.org/10.1016/oo3o-4387(94)9o164-3.

11 Cornell and Starr, Modernization and Regional Cooperation, 7 (emphasis added).

12 Kristiina Silvan, "Uzbekistan's New Central Asian Policy," FIIA Working Paper 120, November 2020, https://www.fiia.fi/wp-content/uploads/2020/11/wp12O_uzbekistans -new-central-asia-policy.pdf, 10.

13 Collins, "Economic and Security Regionalism."

14 Allison, "Virtual Regionalism."
} 
Third, different levels of economic development and nation-/state-building, not to mention political disagreements, are arguably not conducive to the spirit of sustained and genuine cooperation that is the precondition for the creation of a working regional platform. ${ }^{15}$ The economies of Kazakhstan and Uzbekistan, for example, not only differ in quantitative terms from those of Kyrgyzstan and Tajikistan, but are also quite different from each other. In addition, substantial disagreements over the management of strategic natural resources such as water and energy assets-as well as heavy economic dependence on extra-regional actors that have their own regionalist projects to pursue- have made the idea of a Central Asian regional organization impracticable in recent years.

Fourth, much of the economic gravitational pull for the Central Asian states is exogenous and centrifugal - that is, the regional economies depend on the supply-and-demand created by neighboring great powers and external economic partners far more than on each other's market dynamics. ${ }^{16}$

These four conditions, while certainly not exhaustive, are indicative of some of the major trends found in the majority of recent Western literature on Central Asian regionalism, notwithstanding innovative recent attempts to better understand the social, political, and security context of Central Asian regionalism. ${ }^{17}$

That regionalism has not (yet) taken off in the region is a matter of fact, and the literature has done an excellent job of discussing why this has been the case. What is problematic is that much of this literature refers to regionalism as an undisputed, almost innocent category into which the political reality of Central Asia must fit - and, most importantly, seems to suggest that only through the lens of regionalism can we make sense of the international politics of Central Asia. Albeit implicitly, regionalism seems to be employed as a normative category with a specific yet nuanced prescriptive message, affecting how scholarship on and from the region is produced and, therefore, how the region is widely perceived. ${ }^{18}$

15 Kubicek, "Regionalism, Nationalism and Realpolitik."

16 Krapohl and Vasileva-Dienes, "The Region that Isn't."

17 David Lewis, "Central Asia: Fractured Region, Illiberal Regionalism," in Russia Abroad: Driving Regional Fracture in Post-Communist Eurasia and Beyond, ed. Anna Ohanyan (Washington, DC: Georgetown University Press, 2018); Roy Allison, "Protective Integration and Security Policy Coordination: Comparing the SCO and CSTO," The Chinese Journal of International Politics 11, no. 3 (2018): 297-338; Anastassia Obydenkova and Alexander Libman, Authoritarian Regionalism in the World of International Organizations: Global Perspective and the Eurasian Enigma (Oxford: Oxford University Press, 2019).

18 Fora similar point, see Anna Matveeva, "Working Paper13:The Regionalist Project in Central Asia: Unwilling Playmates," Crisis States Research Centre, 2007, https://www.lse.ac.uk/ 
This use of regionalism to assess Central Asian politics is reflected in the following four considerations, ${ }^{19}$ which are also often linked to the concept of integration.

1. The term "regionalism" is often understood as involving either a formal regional organization; a specific, marked, and clearly delineated (and hence possibly exclusionary) identity; or both. While there are many varieties of regionalism, accounts of regional politics in Central Asia often define a region as relying on a specific, exclusive, shared identity, possibly exemplified by the existence of a regional international organization. Krapohl and Vasileva-Dienes have recently argued that "Central Asia as such is nevertheless one of the very few world regions which has not managed to establish a regional organization on its own." ${ }^{20}$ In other words, there seems to be an equation between regionalism and formal regional international organization. Writing in 2004, Bohr lamented that states in Central Asia had been more focused on nation- and statebuilding than "the reabsorption of their newly independent polities into regional organizations requiring the pooling of sovereignty and the formation of supranational structures."21 Bohr further maintained that until Uzbekistan liberalized and engaged in negotiations with neighboring states, "the development of a pan-Central-Asian regional identity [would] remain a chimera," ${ }^{22}$ seemingly assuming that a pan-CentralAsian identity is necessary for the achievement of regionalism-an argument echoed by Olcott. ${ }^{23}$ In September 2020, it was argued in U.S. expert circles that "the absence of an institutional framework owned and managed by Central Asians remains a stumbling block to regional

international-development/Assets/Documents/PDFs/csrc-working-papers-phase-two/ wp13.2-regionalist-project-in-central-asia.pdf, accessed March 5, 2021. On the broader relationship between policy and academic discourses and their effects on perceptions of Central Asia, see, for example, John Heathershaw and Nick Megoran, "Contesting Danger: A New Agenda for Policy and Scholarship on Central Asia," International Affairs 87, no. 3 (2011): 589-612.

19 These considerations are presented separately for purposes of analysis and clarity but should be understood as interrelated.

$20 \quad$ Krapohl and Vasileva-Dienes, "The Region that Isn't," 348.

21 Bohr, "Regionalism in Central Asia," 495.

22 Ibid., 5 O2.

23 Olcott's claim is more substantial: a common, shared identity is the precondition for a region itself, not just regionalism. 
coordination" 24 and that "the coherence and rigor of Central Asia's future institutional structures will determine their effectiveness." ${ }^{25}$ Rosset and Svarin also state that "when speaking of Central Asian regionalism we primarily refer to regional institutional integration among the five [Central Asian republics]."26

2. The term "regionalism" has often had a teleological connotationwhether a group of states already constitutes a region or is struggling to do so, becoming a region is the end goal. Bobokulov maintains that "integration [in Central Asia] is a natural phenomenon that has its own inevitability, based on the geographical proximity and in many instances, contiguity." ${ }^{27}$ Bohr captures this aspect of regionalism's normativity, noting that "in 1991 there was the expectation that the Central Asian states would follow the regionalist course" that was gaining traction elsewhere in the world. ${ }^{28}$ The fact that "even today there is no single body that unifies Central Asia" is puzzling to some. ${ }^{29}$

3. The term "regionalism" is often used prescriptively; regionalism often indicates the right course of action, the appropriate behavior, and/or the norm for states to follow. Most analyses of the regional politics of Central Asian regionalism focus on the lack of regionalism, which the authors of these analyses find puzzling. ${ }^{30}$ Rosset and Svarin, for instance, argue that following the collapse of the Soviet Union, regional integration in Central Asia "seemed logical." ${ }^{31}$ Kols puts the case more strongly: "the path forward for Central Asia must involve real engagement by their own leaders. The international community should support that regional input." ${ }^{32}$ This prescription is often linked to a desire to normalize the Central

24 Marsha McGraw Olive, "Post-COVID-19: Can Central Asia Be Central to Eurasian Integration?" CAP Paper 239, September 2020, https://capgwu.b-cdn.net/wp-content/ uploads/2020/og/CAP-Paper-239-by-Marsha-McCraw-1.pdf, accessed March 5, 2021, 13. Cornell and Starr, Modernization and Regional Cooperation, 10.

26 Rosset and Svarin, "The Constraints of the Past," 246.

27 Inomjon Bobokulov, "Central Asia: Is There an Alternative to Regional Integration?" Central Asian Survey 25, no. 1-2 (2006): 75-91, https://doi.org/10.108o/o26349306oo9o3056, 89.

28 Bohr, "Regionalism in Central Asia," 486 (emphasis added).

29 Richard Kols, "Rising Regionalism: A New Trend or an Old Idea in Need of Better Understanding?" Atlantic Council Paper, September 2019, https://www.atlanticcouncil .org/blogs/new-atlanticist/rising-regionalism-a-new-trend-or-an-old-idea-in-need-of -better-understanding/, accessed March 5, 2021 (emphasis added).

30 Krapohl and Vasileva-Dienes, "The Region that Isn't," 347; Collins, "Economic and Security Regionalism," 250; Kols 2019).

31 Rosset and Svarin, "The Constraints of the Past," 246.

32 Kols, "Rising Regionalism" (emphasis added). 
Asian states, which, "under normal circumstances," Starr argues, "would easily combine in a kind of chemical reaction to create wealth. But in this region at the heart of the Eurasian land mass, circumstances are far from normal." 33 Central Asia's failure to be an integrated region-and hence to be "normal" - leads scholars to regard it with a sense of negative exceptionalism, seeing it as an oddity. When the second consultative meeting between the Central Asian heads of state in 2019 was delayed because of institutional changes in Kazakhstan and the need for newly elected President Kassym-Jomart Tokayev to be installed in power, media analyses were quick to see this as evidence of "suspended integration" in the region. ${ }^{34}$ (Importantly, integration has not been on the agenda of these meetings.)

4. The term "regionalism" is often, albeit implicitly, used with a Eurocentric prism. ${ }^{35}$ This is not to say that regionalism as a practice is Eurocentric per se, as this would mean denying years of scholarship devoted to showing how regionalism has been progressively adopted and localized in non-Western domains. ${ }^{36}$ Rather, the experience of regionalism-and, more importantly, discourses about regionalism - undeniably began in Europe. ${ }^{37}$ Collins, for example, wonders why Central Asia has not coalesced around the logics of regionalism even though "the EU and NAFTA are often touted by international organizations as examples for developing regions to emulate." ${ }^{38} \mathrm{Krapohl}$ and Vasileva-Dienes, assessing the status of regionalism in Central Asia, maintain that "[the lack of regionalism] does not mean that there exists no demand for regional integration in Central Asia, but the demand is different to that in

33 Frederick S. Starr, "A new phase of regional cooperation in Central Asia", Foreign Policy Magazine, Autumn 2004 (emphasis added).

34 Farkhod Tolipov, "Central Asia: Delayed Consultations, Suspended Integration," CACI Analyst, July 2, 2019, https://www.cacianalyst.org/publications/analytical-articles/ item/13578-central-asia-delayed-consultations-suspended-integration.html, accessed March 5, 2021.

35 Importantly, Bohr doubted the utility of Europe-based (neo)functionalism in accounting for Central Asia's lack of regionalism, arguing that it is 'less applicable' to the Central Asian context. Bohr, "Regionalism in Central Asia," 499.

36 Amitav Acharya, "Comparative Regionalism: A Field Whose Time Has Come?" The International Spectator 47, no. 1 (2012): 3-15, https://doi.org/10.108o/03932729.2012.6550o 4; Amitav Acharya and Alastair Iain Johnston, Crafting Cooperation:Regional International Institutions in Comparative Perspective (Cambridge: Cambridge University Press, 2007).

37 Filippo Costa Buranelli and Aliya Tskhay, "Regionalism," in Oxford Research Encyclopaedia in International Studies (Oxford: Oxford University Press, 2019).

38 Collins, "Economic and Security Regionalism," 249. 
economically well-developed regional organizations like the Europe[an] Union (EU)." ${ }^{39}$ Similarly, Boris Rumer argues that "the Central Asian states lack objective preconditions for regional unity in so far as they have neither a shared interest in a single market, as in the European Union, nor large investment resources from one of the member states, as in the North American Free Trade Agreement." 40 In other words, the European and Western experience is seen as a point of comparison, if not a benchmark. According to Kols, "the success of regionalism in Europe can be an important example for the nations of Central Asia." ${ }^{\text {11 }}$ It is perhaps not by chance that the European External Action Service, in its 2020 factsheet on EU-Central Asia Relations, noted that "the new momentum in intra-Central Asia regional cooperation has enhanced the relevance of the EU's own experience in crafting cooperative solutions to crossborder challenges." ${ }^{22}$ Importantly, when the West/Europe is not taken as a benchmark - as perhaps in the case of less formal regional arrangements, such as the Visegrad Group or the Nordic Council—other institutionalized and formalized contexts are framed as examples to imitate; ASEAN, for instance, has been a popular point of comparison. ${ }^{43}$ In other words, "there is no need for regions such as Central Asia to reinvent the wheel" in founding a regional international organization. ${ }^{44}$

Interestingly enough, and as some of the literature discussed above hints at, the Central Asian republics themselves decided to embark on a regionalist project based on ideas that spoke to the European experience of regionalism, such as supranational bodies and a common economic space, at the beginning of the 199os. Not only was their first regionalist project-the Central Asian Union (CAU), founded in 1994-a clear nod to the European Union, which had been created with the Maastricht Treaty a couple of years earlier, but it was also supported by European personnel, advisers, and money. This experience evolved into the Central Asian Economic Cooperation in 1997 and then the Central Asian Cooperation Organization in the early 20oos. The CAU and

\footnotetext{
39 Krapohl and Vasileva-Dienes, "The Region that Isn't," 349.

40 Boris Rumer, quoted in Bohr, "Regionalism in Central Asia," 496.

41 Kols, "Rising Regionalism."

42 European Union External Action Service, "EU-Central Asia Relations," 2020, https://eeas .europa.eu/sites/eeas/files/eeas-ca_ministerial_factsheets-2020-regional-v5.pdf, accessed March 5, 2021.

43 See, for example, Rafael Sattarov, "ASEAN, Uzbek-Style: Tashkent's New Ambitions in Central Asia," Carnegie Moscow Centre, January 19, 2018, https://carnegie.ru/ commentary/75308, accessed March 5, 2021. 
its successors provided a useful set of platforms for the Central Asian states to get to know each other as independent countries in the turbulent postindependence environment, navigate the difficult transition from centralized to open economies (with mixed results across the region), coordinate security, establish diplomatic relations, consolidate strong rule in the region, ${ }^{45}$ offer a set of summits for discussing common problems, and put Central Asia on the map when foreign investments were an absolute necessity. However, these initiatives did not materialize into a sustained, cooperative, formalized Central Asian regionalism. If anything, cooperation has often coexisted with competition and sometimes outright hostility, while bilateralism has often taken precedence over multilateralism.

As I noted in the introduction, the experiences of Central Asian regionalism in the 199os have recently been rediscovered as models and possible starting points for contemporary dynamics in the region, especially when linked to the recent institutional and diplomatic changes in Uzbekistan. These changes are supposedly having a beneficial impact on the regional atmosphere in what seems to be a virtuous circle: changes at the domestic level lead to changes at the regional level, which then feed back into domestic politics. The sudden death of longtime Uzbek president Islam Karimov at the age of 78 on September 2, 2016, has been followed by a series of changes in relations between regional states, the repercussions of which are still unfolding. Shavkat Mirziyoyev, the new Uzbek president, has embarked on a series of reforms in the country's domestic and foreign policy, potentially inaugurating what many commentators see as a new era for regionalism and cooperation in Central Asia. ${ }^{46}$ The

45 Filippo Costa Buranelli, "Authoritarianism as an Institution? The Case of Central Asia," International Studies Quarterly 64, no. 4 (2020): 1005-1016, https://doi.org/10.1093/isq/ sqaao58.

46 For a summary, see Alberto Turkstra, "Central Asian Leaders Summit Signals New Era for the Region, Says EIAS Programme Coordinator Alberto Turkstra," European Institute for Asian Studies, http://www.eias.org/news/central-asian-leaders-summit-signals-new-era -for-the-region-says-eias-programme-coordinator-alberto-turkstra/, accessed December 16, 2020; Takehiko Nakao, "A New Era of Cooperation for Central Asia," The Astana Times, October 27, 2017, https://astanatimes.com/2017/10/a-new-era-of-cooperation -for-central-asia/; Zhyldyz Urmanbetova, "Byt' li region Tsentral'noi Azii?" Akipress, June 6, 2020, http://analitika.akipress.org/news:5642, accessed June 14, 2020; Bakhri Bakhriev, "Tsentral'naia Aziia: formirovaniie soobshchestba bezopasnosti?" International Studies, March 22, 2018, http://internationalstudies.ru/tsentralnaya-aziya -formirovanie-soobshhestva-bezopasnosti/, accessed March 5, 2021; Rustami Sukhrov, “Tsentral'naia Aziia-neslozhivshaiasia integratsiia?" Central Asian Analytical Network, June 4, 2020, https://caa-network.org/archives/199o9, accessed March 5, 2021; Bruce Pannier, "A New Era Of Central Asian Cooperation? Uzbekistan, Kazakhstan Help a Neighbor in Need," Radio Free Europe/Radio Liberty, November 14, 2020, 
discussion above hints at the fact that "while the Central Asian elites referred to historical events to justify the five stans discourse, the scholars who deal with Central Asia produced and reproduced this discourse by trying to fit the logic of regional integration into the five stans discourse." 47

These reflections have led me to reconsider the term "regionalism" and its application to Central Asia. If states do not cooperate and integrate, how do they still coexist? Is it perhaps that international relations in Central Asia are structured according to logics that differ from those of regionalism? In other words, what if scholarship has looked for something that does not exist (or does not yet exist) in the region? What if the frustration in seeing ill-defined logics and practices of regionalism has to do with the fact that we are dealing with something else in Central Asia? The literature reviewed above has the merit of discussing and analyzing what Central Asia is not. The question we are left with is: If regionalism has not taken off in Central Asia, then what are we dealing with? In the next section, I introduce the concept of order, which may be more pertinent and more appropriate to international relations within the region.

\section{The Concept of Order}

I argue that the concept of order is more fitting, more appropriate, and more analytically clear with respect to Central Asian political life than integrationoriented regionalism. As argued in the introduction, order refers to a more-orless stable, predictable set of relations that makes it possible for the basic goals of a given social context to be achieved by implementing rules and institutions that enable and protect common interests. Aside from history-informed and post-positivist readings of Hegemonic Stability Theory, constructivism and the English School of international relations are perhaps the two traditions that have most endeavored to study world politics not simply in terms of anarchy and power, or cooperation and "games," but rather as a social context in which order is continuously negotiated, debated, implemented, and produced.

https://www.rferl.org/a/new-era-of-central-asian-cooperation-uzbekistan-kazakhstan -help-a-neighbor/30950079.html, accessed March 5, 2021; Yi Da Jeremy Ng, "The Rise of Regionalism in Central Asia?", The Diplomat, April 2, 2018, https://thediplomat.com/ 2018/04/the-rise-of-regionalism-in-central-asia/, accessed March 5, 2021.

47 Ulugbek Azizov, "Regional Integration in Central Asia: From Knowing-That to Knowing-How," Journal of Eurasian Studies 8, no. 2 (2017): 123-135, https://doi.org/10.1016/ j.euras.2017.02.002, 131 . 
Following Hedley Bull, it may be said that any social context that does not fall prey to unrestricted and endemic violence achieves at least the following three goals: preservation of life, control of violence, and observance of promises and agreements. ${ }^{48}$ Without these, any order is unsustainable and its members can neither thrive nor establish meaningful relations with one another. "To say that $x$ is in someone's interest is merely to say that it serves as a means to some end that he is pursuing." 49 Of course, interests can vary, both in kind (security, economic development, or ideological objectives) and in degree (security may be more important than economic development, or vice versa). Yet "however different and conflicting [states'] objectives may be, they are united in viewing these goals as instrumental to them."50

These fundamental goals, necessary to realize individual interests, are achieved through the observance and implementation of rules, which serve as normative and behavioral standards, demanding that a specific principle (or set of principles) be respected if social life is to prosper and thrive. Such rules do not have to be understood solely through the lens of legal positivism - that is, they do not have to be found only in treaties and contracts. Indeed, "it is not uncommon for a rule to emerge first as an operational rule, then to become established practice, then to attain the status of a moral principle and finally to be incorporated in a legal convention." ${ }^{51}$

Rules can, of course, regulate a wide range of activities and can vary in their nature and complexity. In international relations, three types of rules may be defined as the most significant. First, there are constitutional rules: prescriptions that define the "DNA" of the social order under consideration. The analog in world politics is the fundamental rule that only sovereign states are members of the international order; other possibilities, such as a universal empire, a cosmopolitan community of human beings, or a Hobbesian state of nature or state of war have been ruled out for at least the foreseeable future. ${ }^{52}$ The second set of rules refers to rules of coexistence, which are designed to minimize violence and to make the social order as predictable and stable as possible. The third, more advanced, complex of rules is about cooperation - that is, belonging to a social order "in which a consensus has been reached about a wider range of objectives than mere coexistence."53

48 Hedley Bull, The Anarchical Society: A Study of Order in World Politics (Basingstoke: Macmillan, 1977).

49 Ibid., 66.

$50 \quad$ Ibid., 67 .

51 Ibid., 67.

$5^{2}$ Ibid., 68.

53 Ibid., 7 o. 
All these rules are produced and reproduced in the workings of institutions, defined as a set of durable discourses and practices about what is doable, appropriate, permissible, and right in a given social order. ${ }^{54}$ These institutions are not, as liberal theorists working in the regime theory tradition might argue, (merely) international organizations. Instead, they are to be understood in a more anthropological and sociological sense, as codified and established discourses and practices that define, regulate, and legitimize the social life in each order.

In international relations, institutions are understood as the ensemble of rights and responsibilities held by great powers in the international system: sovereignty, international law, diplomacy, and great power management. ${ }^{55}$ Institutions understood in neoliberal terms, i.e., international organizations, may well be related to institutions as understood here in the sense that they embody, represent, and make manifest these more intangible practices, discourses, and habits. For example, the General Assembly of the United Nations (UN) is said to represent the institution of sovereignty (one head one vote), while the U.N. Security Council represents the institution of great power management. Yet it is worth remembering that when we speak of order and institutions, "by an institution we do not necessarily imply an organisation or administrative machinery, but rather a set of habits and practices shaped towards the realisation of common goals." 56

Before considering Central Asia, let us pause for a moment to compare the concepts of regionalism and order. Regionalism can be seen as a specific logic of order; it is based on a specific set of goals, rules, and institutions aimed at fostering cooperation and advanced coordination between states and societies in a limited and well-defined geographical area. Regionalism is also a set of discourses, practices, and normative commitments (often based on a common identity) that may vary depending on the level of cooperation that the parties seek-pragmatic, functional, or integrationist-all carried out through the workings of a (set of) regional organization(s). For regionalism to take off in a given region, the social order in that region must be developed and complex enough to allow trust between the parties to foster advanced cooperation in some areas of common-interest concern. Order does not necessarily require this. Order is a more neutral, minimalist, and normatively lighter concept, as it refers simply to the basic structure (in terms of actors and rules linking them)

54 Barry Buzan, From International to World Society? English School Theory and the Social Structure of Globalisation (Cambridge: Cambridge University Press, 2004).

55 For a broader list, see Buzan, From International to World Society?

$5^{6}$ Bull, The Anarchical Society, 74. 
of a given social context (in this case, Central Asia). Order encapsulates the basic, defining, and fundamental norms, principles, values, and rules that actors must follow in order to, at a minimum, live and let live. In other words, regionalism presupposes an order, but an order does not necessarily have to morph into regionalism. For the information-technology-oriented reader, regionalism may be thought as software and order as hardware.

It may be useful to see how order relates to the four propositions set out above. First, I argued that the term "regionalism" can be read as linked to formal organizations and/or a specific regional identity. Order does not necessarily imply this, as it allows for dynamics that do not necessarily pertain to the constitution of a regional group of states or a formalized regional international organization. Also, order can assume a variety of forms (anarchical, hierarchical, homogeneous, mixed, and so forth) that can also be studied historically and diachronically. In other words, order is malleable and adaptable; it may be formalized and rest on a common identity, but the contrary may also be true. ${ }^{57}$ Second, I explained that the term "regionalism" can be used teleologically, referring to the necessary creation of a region. On the other hand, order is always contingent and historically situated; it can be expressed along regional lines, but can also assume other forms and can range from minimal, basic coexistence to quasi-federative logics. ${ }^{58}$ Third, I stated that the term "regionalism" is often applied to Central Asia as a prescriptive policy indication. Here, one may argue that order is also a prescriptive term, as it pertains to a rational, conflictavoiding set of ideas and rules that may have to do with a specific understanding of how politics should be done based on shared norms and principles. After all, "to bring order" is a normative statement. At the same time, however, one may argue that this is what political communities have been trying to do throughout history ${ }^{59}$ and that episodes of unrestrained, continuous, and widespread violence are usually the exception (and themselves lead to some new forms of order). Fourth, I posited that the term "regionalism" as deployed in the Central Asian context is often laden with a Eurocentric set of attributes or seen as a European/Western benchmark for Central Asia. While on a lexical level this may hold (note that "order" comes from the Latin ordo, which means "disposition" and "arrangement," but also "system" and "regularity"), order in the sense of a social configuration can undeniably be found in different times

$57 \quad$ One may argue that we can speak of an international order without necessarily implying an international identity, something that vanguardist readings of internationalism would perhaps imply with respect to communism, democratic peace theory, and the like.

58 Buzan, From International to World Society?

59 Barry Buzan and Richard Little, International Systems in World History: Remaking the Study of International Relations (Oxford: Oxford University Press, 200o). 
and spaces, as political organizations based on rules of coexistence (however codified) are a hallmark of world history—not just European history. ${ }^{60}$

Having clarified the distinctions and links between regionalism and order, and having accepted the premise that Central Asia is not (yet) undergoing processes that would fall under the label of regionalism, can Central Asia be said to represent an order as defined above? In the following section, I apply the theory of order outlined above to the regional politics of Central Asia.

\section{$3 \quad$ Central Asia as an Order}

Based on recent scholarship on the region ${ }^{61}$-and notwithstanding the fact that we cannot speak of regionalism in Central Asia and cannot see the foundation of an autochthonous regional international organization except for the International Fund for the Aral Sea-Central Asia may well be said to constitute an order. The institutions underpinning such an order, to be discussed later, are those of sovereignty, diplomacy, international law, authoritarianism, and great power management. In previous works, I have discerned the presence, and indeed the operation, of these institutions through primary research (in the form of fieldwork, elite interviews, and archival research conducted between 2013 and 2019), secondary research, and observable patterns of behavior of the Central Asian republics over time. All of them have abided by these institutions since independence in 1991, which has helped prevent open inter-state conflict from erupting and has also minimized violence-although it is important to stress that this institutional alignment has not necessarily occurred without violence, instability, episodes of power politics, and marked antagonism between different states in the region.

Now, let us discuss the Central Asian order following the steps outlined in the previous section. First, were and are the elementary goals present? I would be inclined to say yes. As soon as the Central Asian republics became independent, their most pressing imperative (or that of their official representatives)

6o For an overview, see Andrew Phillips and J.C. Sharman, International Order in Diversity: War, Trade and Rule in the Indian Ocean (Cambridge: Cambridge University Press, 2015).

61 Filippo Costa Buranelli, "May We Have a Say? Central Asian States in the UN General Assembly," Journal of Eurasian Studies 5, no. 2 (2014): 131-144, https://doi.org/10.1016/ j.euras.2014.05.002; Filippo Costa Buranelli, "World Society as a Shared Ethnos and the Limits of World Society in Central Asia," International Politics 55, no. 1 (2018): 1-16; Filippo Costa Buranelli, "The Heartland of IR Theory: Central Asia between Realism and Liberalism" in Theorizing Central Asian Politics, ed. Rico Isaacs and Alessandro Frigerio (Houndmills: Palgrave Macmillan, 2019), 237-261; Lewis, "Central Asia: Fractured Region." 
was to tame ethnic and territorial conflict, thereby avoiding a Caucasian or Yugoslavian scenario and making it possible to embark on state- and nationbuilding processes without being crippled by possible conflict with neighbors over minorities, enclaves, natural resources, borders, and so forth. The Central Asian states' governments and diplomatic officials wanted - and still wantthe assurance that no territorial claim will be made and that the basic agreements on the elementary rules of coexistence will be respected. Furthermore, they wanted - and still want - to preserve the state as the only recognized, authoritative source of political and military power in the region, thus thwarting any attempts to establish alternative centers and sources of power (e.g., panTurkism in the early 199os, discourses for a united Turkestan in the mid-199os, and Isis and the Caliphate today).

In terms of rules, these fundamental goals had to be (and must currently be) achieved through the operation of some basic, straightforward, and agreed-upon codes of conduct that all states are expected to observe. First and foremost are the rules regulating non-intervention and non-interference. Respecting each other's sovereignty, preserving some sort of balance of power, avoiding acting as a "big brother," and refraining from establishing a brazen regional hegemony: these are all rules that states understand and embrace. To be sure, that these rules exist does not automatically mean that they are scrupulously observed at all times. This would amount to an ideal-typical situation that is not mirrored in international relations, let alone in domestic societies; the fact that there are rules does not mean that rules cannot be broken. Importantly, however, whenever these rules have been broken, state representatives and diplomats have always either justified themselves for doing so or indicated that in their view the rules were not violated, thus acknowledging the rules' existence.

Another rule that all Central Asian states follow is protecting territorial integrity as inherited from the Soviet Union-in other words, respect for the principle of uti possidetis. Observance is also demanded in the macro-regional context, as demonstrated by Central Asian countries' wariness with respect to the annexation of Crimea. ${ }^{62}$

A third rule that visibly operates in the region is that the neighboring great powers operating in the regional context (mostly Russia and China) must be

62 Emilbek Dzhuraev, "Central Asian Stances on the Ukraine Crisis: Treading a Fine Line?" Connections 14, no. 4 (2015): 1-10; David Trilling and Joanna Lillis, "Russia-Ukraine Crisis Alarms Central Asian Strongmen," Eurasianet, March 4, 2014, https://eurasianet.org/ russia-ukraine-crisis-alarms-central-asian-strongmen, accessed March 5, 2021. 
balanced through a mix of economic and military multi-engagement, a behavior the literature has called omni-balancing or multivectorism. ${ }^{63}$

The fourth, overarching rule is the preservation of avtoritet and stabil'nost'.64 One might say the workability of order in the region depends on this rule. It does not really matter if leaders like each other or whether cooperation or competition is the prevalent mode of social interactions between regional states, because leaders refrain from interfering in each other's political domain, legitimize each other's tenure in power, and seek to minimize abrupt leadership changes in the region.

Finally, what are the institutions that ensure that these rules are operative, protected, upheld, and legitimized? First is the institution of sovereignty. Each Central Asian state has learned over the years to respect the others' sovereignty, to voice concerns when it detects a lack of this respect, and to claim sovereignty to be the foundational institution of the Central Asian regional order - to the point, one may argue, of hindering more advanced and sustained forms of cooperation. ${ }^{65}$

Second is the institution of diplomacy. States in the region communicate through official channels, operate embassies and consulates on each other's territories, conduct meetings at the presidential and ministerial levels, strive to abide by a diplomatic code of conduct even during the most heated controversies (such as the building of the Rogun dam), and privilege peaceful resolution of conflict as the preferred means of interaction in the region. This diplomacy and conflict management is often performed through a combination of interpresidentialism and on-the-ground actors - such as heads of municipalities and representatives of border communities - who resort to local and informal practices of peace-making and -keeping. ${ }^{66}$ It is these relations that construct

63 Kirill Nourzhanov, “Omnibalancing in Tajikistan's Foreign Policy: Security-Driven Discourses of Alignment with Iran," Journal of Balkan and Near Eastern Studies 14, no. 3 (2012): 363-381, doi:10.108o/19448953.2012.720784; Nicola P. Contessi, "Foreign and Security Policy Diversification in Eurasia: Issue Splitting, Co-Alignment, and Relational Power," Problems of Post-Communism 62, no 5 (2015): 299-311, https://doi.org/10.1080/1 0758216.2015.1026788; Costa Buranelli and Tskhay, "Regionalism." For a recent criticism, see Luca Anceschi, Analysing Kazakhstan's Foreign Policy: Regime neo-Eurasianism in the Nazarbaev era (Abingdon: Routledge, 2020).

64 John Heathershaw, "New Great Game or Same Old Ideas? Neo-Sovietism and the International Politics of Imagining 'Central Asia," in The CIS: Form or Substance? Ed. David Dusseault (Helsinki: Kikimora, 2007), 237-268; Costa Buranelli, "Authoritarianism as an Institution?".

65 Costa Buranelli, "World Society as a Shared Ethnos."

66 Madeleine Reeves, ed., Movement, Power and Place in Central Asia and Beyond: Contested Trajectories (London: Routledge, 2012); Nick Megoran, Nationalism in Central Asia: 
and sustain a sense of good-neighborliness and uphold 'the neighborhood' not only as the fundamental, pivotal discourse of coexistence in Central Asia, but also as the territorial framework for the conduct of inter-state relations in the region.

In recent times, representatives of local communities, border guards acquainted with communities living on the disputed segments of the border, and institutional dialogue (which is smoother in the Kyrgyz-Uzbek case than in the Kyrgyz-Tajik one) played a role in containing violent border clashes on the Kyrgyz-Uzbek and Kyrgyz-Tajik borders and obtaining foreign aid in the form of food, primary goods, medical supplies, and expertise from the other countries of the region (with the exception of Turkmenistan). The presidents and ministerial agencies tackling the pandemic initiated a web of contacts and reciprocal discussions on the epidemiological situation in their respective states. While multilateralism does not yet seem to be fully institutionalized, the web of overlapping bilateral (and sometimes trilateral) relations in the region is nonetheless solid and active. In a recent example, the governments of Kazakhstan and Uzbekistan decided to support neighboring Kyrgyzstan with humanitarian aid thanks to the coordination of health agencies in the three countries. ${ }^{67}$

In addition, Uzbekistan has embraced multilateralism more consistently and has launched the idea of an informal Central Asian dialogue on security as well as economic, territorial, and political issues. This idea, dubbed in some circles the "Samarkand Spirit," is enshrined in UN resolution A/RES/72/283. Two consultative meetings of the heads of state of Central Asia have sprung from this initiative - the first in Astana (now Nur-Sultan) in 2018 and the second in Tashkent in 2019. Alongside these informal meetings, foreign affairs issues are also back on the radar, with Central Asian foreign ministers now meeting regularly after more than a decade of intermittent, haphazard dialogue. The purpose of this flexible, adaptable, non-committal, and pragmatic dialogue is for Central Asian states to update each other on issues relevant to systemic aspects of regional politics. Cooperation has become voluntary, consensual, and informal. Yet contemporary analysts of these dynamics still dismiss them as "confabbing," "flowery language," "chatter," and "boilerplate statements."68

A Biography of the Uzbekistan-Kyrgyzstan Boundary (Pittsburgh, PA: University of Pittsburgh Press, 2017).

67 Pannier, "A New Era of Central Asian Cooperation?"

68 "Central Asia Leaders Confab but Stop Short of Binding Commitments," EurasiaNet, March 16, 2018, https://eurasianet.org/central-asia-leaders-confab-but-stop-short-of -binding-commitments, accessed March 5, 2021. 
International law is the third institution upholding order in the region. UN treaties and conventions are invoked and adopted, especially when it comes to territorial matters, security issues, and management of natural resources. A good example is the oft-neglected Central Asian Nuclear-Weapon-Free Zone and the preparatory work behind its creation. ${ }^{69}$ Treaties, memoranda, protocols, and conventions are used, signed, and ratified-yet flexibility, informality, and non-binding "soft" tools of agreement such as broad discussions and verbal agreements are also in play. At the regional level, in recent years, multilateral agreements and regional conventions have been almost purposefully avoided, as regional leaders are focusing more on a behavioral code of conduct based on consensus and flexibility than on binding agreements. A mix of formalized and informal relations between the regional states thus helps constitute the backbone of coexistence and cooperation in Central Asia. As Uzbek president Shavkat Mirziyoyev recently argued, Central Asian presidents meet and discuss not to institutionalize a new regional organization, but merely to "sync their watches."70

Fourth, there is authoritarianism. The institutionalization of authoritarianism, often linked to seniority and paternalism - as evidenced by the honorific titles bestowed on Central Asian presidents-has been progressively legitimized in the region through the adoption of strong rule and authoritarian practices by the Central Asian states, on the one hand, and the delegitimization of alternative, more pluralistic forms of government whenever these have been pursued, on the other hand. The 2005 and 2010 revolutions in Kyrgyzstan are an example of delegitimization, ${ }^{71}$ which has served almost as an exclusion from a club of like-minded states. This meshes with the definition of "institution" provided above, which stresses both regulatory practices and the definition of identities and membership criteria within a specific social group. The authoritarian governance widely adopted in the region, its acceptance by regional states (granted, with marked differences within each state), and the shared understanding that instability in a country is a potential threat to rule (and the ruler) in other regional states points to the plausible existence of a raison de système (as opposed to a realist raison d'état), which is typical of a social context structured as an order. Recent work on illiberal and

69 Nuria Kutnaeva, ThePoliticalAspectof theFormation of a CentralAsianNuclear-Weapon-Free Zone (Bishkek: Boris Yeltsin Presidential Library, 2013), https://www.prlib.ru/en/item/ 694644; Cornell and Starr, Modernization and Regional Cooperation.

70 "Central Asia Needs Joint Search for Solutions to Regional Problems-Mirziyoyev," Central Asia General Newswire, November 10, 2017, accessed through LexisNexis on June 29, 2020.

71 The fine-grained institutionalization of authoritarianism in Central Asia is accounted for in Costa Buranelli, "Authoritarianism as an Institution?". 
authoritarian peacebuilding in the region has also considered these practices' structuring effects. ${ }^{72}$

Finally, there is the institution of great power management. This institution is the set of practices, discourses, and ideas that allow great powers to take over responsibilities in the face of (perceived or real) existential threats to the Central Asian order, grounded mostly in these great powers' capabilities, special rights, and responsibilities. No Central Asian state, for example, disputes the fact that Russia (as well as, perhaps to a lesser extent, the US) is allowed to and in fact must keep the situation in Afghanistan in check. Yet it is clear that this institution is in tension with that of sovereignty, as great power management may easily slide into violations of the sovereign prerogatives of regional states. As Nazarbayev has recently argued,

Of course, we [Central Asian states] all have two big partners and neighbors: Russia and China. We will always work together with them. All of our agreements remain in force, despite the fact that some of our countries are EurAsEC [Eurasian Economic Community] members, some Collective Security Treaty Organization (CSTO) members, and some not, but that's not what matters. However, we should resolve our own issues without involving third parties. ${ }^{73}$

A recent example of (attempted) great power management occurred in relation to the border issues I mentioned when discussing diplomacy's role in the Ferghana valley. At a recent meeting of сзто delegates, Russian Foreign Minister Sergei Lavrov suggested Russia as a mediator between Kyrgyzstan and Tajikistan, as well as declaring Moscow's readiness to play bona officia in the demarcation of borders. Paradoxically, and perhaps ironically, Lavrov's offer managed to put the two conflicting parties on the same page: both Bishkek and Dushanbe rejected Russia's involvement in the border question, arguing that this was a sovereign prerogative of the two states and that an offer of mediation would constitute interference in the internal affairs of the two countries. ${ }^{74}$ Kyrgyzstan and Tajikistan's reaction to Russia's offer, as well as

72 For example, David Lewis, John Heathershaw, and Nick Megoran, "Illiberal Peace? Authoritarian Modes of Conflict Management," Cooperation and Conflict 53, no. 4 (2018): 486-506, https://doi.org/10.1177/oo10836718765902.

73 Central Asia General Newswire, "Central Asia Needs Joint Search."

74 "Kyrgyz Foreign Ministry Replied to Lavrov's Statement over Readiness of Russia to help Kyrgyzstan, Tajikistan to Settle Border Issue," Akipress, May 30, 2020, https://m.akipress .com/news:642578:Kyrgyz_Foreign_Ministry_replied_to_Lavrov_s_statement_over _readiness_of_Russia_to_help_Kyrgyzstan,_Tajikistan_settle_border_issues/, accessed 
Moscow's recent attempts to navigate the delicate political dynamics in the region, confirm recent research findings on the negotiated nature of Moscow's hegemony in the region, which is fundamentally dependent on the Central Asian countries' consent and never amounts to mere primacy. ${ }^{75}$

Not only have the workings of the above institutions preserved Central Asia from descending into open conflict and becoming a regional Hobbesian state of nature, but they have also created the conditions for better coordination, pragmatic coexistence, flexible cooperation, and informal consultationsimplemented in a cautious way and sometimes marked by disagreements and conflict, yet stable and accepted by all parties involved. ${ }^{76}$

In sum, the discussion above suggests the existence of an order in Central Asia that very much depends on the states' presidents' agreement to avoid open conflict and competition, as these may lead to instability and, consequently, to their loss of personal power and the potential for exploitation by neighboring great powers. This order is premised on the values of preservation of (political) life, control of violence, and respect of agreements, and it is sustained by the institutions of sovereignty, diplomacy, authoritarianism, international law, and great power management - a very state-centric, elite-based consensus that arguably privileges the inter-state domain over the inter-human one by fostering what has been called an illiberal peace. ${ }^{77}$

What about the place of Central Asian order in the macro-regional environment? This order is institutionally and normatively supported by a complex set of formal regional organizations. These organizations- the Shanghai Cooperation Organization, the Commonwealth of Independent States, and the Collective Security Treaty Organization, among others-facilitate dialogue between Central Asian governments by providing venues for discussing matters of common concern and by locking in specific values and principles that

March 5, 2021; "Tajikistan Sends Note to Russian Foreign Ministry on Lavrov's Statement About Tajik-Kyrgyz Border," Akipress, June 1, 2020, https://akipress.com/ news:642621:Tajikistan_sends_note_to_Russian_Foreign_Ministry_on_Lavrov $\% \mathrm{E} 2 \% 8 \mathrm{\circ} \%$ 99s_statement_about_Tajik-Kyrgyz_border/, accessed March 5, 2021.

75 Filippo Costa Buranelli, "Spheres of Influence as Negotiated Hegemony-The Case of Central Asia," Geopolitics 23, no. 2 (2018): 378-403, https://doi.org/10.1080/14650045.2017 .1413355 .

76 Slavomír Horák, "Central Asia After Astana: From Integration to Cooperation," CACI Analyst, April 30, 2018, https://www.cacianalyst.org/publications/analytical-articles/ item/135०9-central-asia-after-astana-from-integration-to-cooperation.html, accessed March 5, 2021.

77 Catherine Owen et al., Interrogating Illiberal Peace in Eurasia: Critical Perspectives on Peace and Conflict (Lanham, MD: Rowman \& Littlefield, 2018). 
underpin the above institutions. ${ }^{78}$ The reader may argue that the norms and institutions embodied in these organizations, especially sovereignty, diplomacy, and international law, facilitate interactions between most states across the world, and certainly in the macro-regional setting encompassing Eurasia and South Asia, and thus are not exclusively 'Central Asian'. And yet, one can nonetheless recognize a 'Central Asian' regional order in the minds of leaders and officials. Here is where discursive, rhetorical politics has its importance, and where the way in which élites talk and relate to their neighbors constitutes and constructs the regional environment. The use of 'Central Asia' as a shared imagined space that binds together the regional states keeps dialogue alive; creates a sense of belonging; stresses commonalities that are cultural, historical, and religious; and places the republics on the international mapuseful for issues pertaining to development, environmentalism, and security. Several things markedly delimit Central Asia to the five post-Soviet republics, including the most recent consultative meetings of the Central Asian Heads of States and the initiatives that followed (such as the boosting of cultural diplomacy to facilitate trust-building and people-to-people linkages), as well as the statement released during the October 2020 events in Kyrgyzstan. ${ }^{79}$ Adopting order as an analytical lens to study Central Asian politics also makes it possible to account for Turkmenistan, something that a regionalist approach cannot do, given Ashgabat's insistence on isolationism and "positive neutrality." ${ }^{\prime 0}$ Furthermore, periodic attempts on the part of Uzbekistan to include Afghanistan in the regional complex-especially through participation in the peace-making process there-seem to be more part of Uzbekistan's wider strategy for taking ownership of the process than a genuine redefinition of the regional contours of Central Asia, although this may well change in the future. Simultaneously, recent scholarship has shed light on how the Central Asian republics instrumentally and tactically play at different regional tables and deploy different identities to fend off great power pressure and the

78 Alessandra Russo and Edward Stoddard, "Why Do Authoritarian Leaders Do Regionalism? Ontological Security and Eurasian Regional Cooperation," The International Spectator: Italian Journal of International Affairs 53, no. 3 (2018): 20-37, https://doi.org/10.108o/o393 2729.2018.1488404.

79 Tatyana Kudryavtseva, "Presidents of Four Republics Make Appeal on Situation in Kyrgyzstan," 24.kg, October 9, 2020, https://24.kg/english/168557_Presidents_of_four _republics_make_appeal_on_situation_in_Kyrgyzstan/, accessed March 5, 2021.

8o This is epitomized by Rosset and Svarin, quoting Bohr: "In this article, however, we exclude Turkmenistan from the discussion because the country followed a firmly isolationist path and 'has set itself apart from the phenomenon of regionalism altogether." See Rosset and Svarin, "The Constraints of the Past," 246. 
encroachments of power politics. ${ }^{81}$ Thus, the concept of order presented in this paper should not be interpreted as too rigidly exclusionary.

Before concluding this section, I offer two additional thoughts to further clarify what the concept of order as employed here means and entails. First, the fact that there is an order does not mean that there is an absence of disagreement, conflict, or violence. Central Asia is often a theatre of skirmishes and quarrels, both at the state level (as with the recent and protracted hurdles and reciprocal accusations on the Kazakh-Kyrgyz border with respect to the free transit of goods and commercial vehicles) and the people-to-people level (the aforementioned border conflicts). Simply, the fact that there is an order means that there is a set of rules and thresholds and that all players (states) understand that it is in their interest not to violate them constantly-for the viability of their political project depends not on the raison d'état, as a realist would maintain, but on a shared raison de système. As for conflict, competition, and episodes of violence, these are common to all social contexts (from families to large-scale societies) and their presence should be no surprise. Should they become pervasive and uncontrolled, though, that would mean the collapse of a given order. This is what the literature on (the absence of) regionalism in Central Asia has often emphasized and perhaps over-emphasized: it has mostly stressed the presence of conflict, competition, frictions, and disagreements, as well as the lack of formalized structures for cooperation, a focus that has cast a shadow on other, more basic and yet fundamental patterns of relations and coexistence between the Central Asian republics. Order is never fixed but is always negotiated, contested, produced, and reproduced through discourses and practices at different levels.

Second, the fact that order as depicted above is very much state-centric and dependent on an inter-elite understanding of stability and predictability does not necessarily mean that non-state actors are excluded from it; this is a specific methodological choice I consciously adopt in this paper, but this does not mean that it is a priori exclusionary. In fact, as noted when analyzing the operation of diplomacy in the region, local and border communities are very much involved in maintaining stability and peace in the most sensitive areas, often thanks to rules and practices that may have nothing to do with international law but are more rooted in local and precolonial sources of legitimacy and acceptance. Moreover, dialogue between intellectuals, scholars, and analysts on Central Asia's status - carried out in seminars, roundtables, media

81 Aliya Tskhay and Filippo Costa Buranelli, "Accommodating Revisionism through Balancing Regionalism: The Case of Central Asia," Europe-Asia Studies, 72, no. 6 (2020): 1033-1052, https://doi.org/10.108o/og668136.2020.1779184. 
appearances, and research centers-also favors a discourse of togetherness that, if not fully manifested in regionalist and integrationist logics, nonetheless underpins a sense of order and good-neighborliness. The Central Asian order depicted in this paper is a complex, multi-layered one with different worldviews and imaginaries. The state-centric approach of this paper is one way to look at it, but arguably not the only way.

My thoughts presented above on the constitution and operation of the Central Asian order are intended to make an initial, suggested, and tentative case for seriously considering the presence of dialogue, common understandings, and "red lines" between Central Asian states even in the absence of regionalist and integrationist dynamics.

The concept of order, more basic and less normatively burdensome than that of regionalism, seems to be more faithful to what is happening in the region, both from a discursive and a pragmatic viewpoint, especially when relying on what anthropologists would call emic accounts of political life - that is, when discourses and practices make sense and have purposeful social value and legitimacy for the actors immersed in the context of study. Regionalist and integrationist impulses from the early and mid-19gos have yielded ground to discourses centered on coordination, mutual listening, compromise, and pragmatism, rather than aspirational designs of institutionalized multilateralism. Given the underlying distrust between governments in the region, at least until a couple of years ago, this should be interpreted as a welcome result. A focus on order also helps us understand that the absence of purely Central Asian regional organizations or the fact that membership in other platforms is shared with neighboring great powers is not necessarily a failure of Central Asian regionalism but rather is a practice of order-making and order maintenance in itself. Adopting order as an analytical category to describe Central Asia and its political life does not, however, mean completely ruling out the concept of regionalism, assuming it is interpreted in a non-formalized way. In fact, new literature on informal and "fringe" regionalism has made the case for escaping the Eurocentric trap of formality and looking at actual practices of cooperation and multilateral interaction, taking into account different levels of analysis. ${ }^{82}$ In my assessment, this form of regionalism may still find fertile

82 Frank Mattheis, Luca Raineri, and Alessandra Russo, Fringe Regionalism: When Peripheries Become Regions (Basingstoke: Palgrave Pivot, 2018); Kairat Moldashev and 
ground in Central Asia. Yet this present time is probably one of consolidating the rules of coexistence and finding ways to make them fully predictable; as such, speaking of order seems to be more accurate and perhaps preferable. By focusing on order, we as scholars can dig out the fundamental principles that would define the backbone of any regionalist enterprise, which will be clear to us only after having understood and interpreted the underlying norms, institutions, and interpretations thereof that are at play in Central Asia.

These reflections should be tied to broader considerations about what the future of the international liberal order (if indeed it has one) entails. If the international liberal order is receding and a more pluralistic, region-based order is rising, ${ }^{83}$ then it is reasonable to expect regions to maintain their fundamental ties to the global level (especially the market and trade structure of the global economy) while at the same time cultivating embedded pluralism ${ }^{84}$ revolving around local institutions and indigenous interpretations of global ones such as sovereignty and international law. As discussed above, this can be done through a mix of formality and informality, or through the institutionalization of practices that are absent from the liberal, Western world (as in the case of strong rule). But there may be other ways to achieve this, which brings me, however briefly, to possible trajectories for further research.

I hint at three possible trajectories. First, works on Central Asian order may genuinely benefit from sociological and anthropological studies on bottom-up cooperation and cross-border interactions in the region. International Relations has an advantage in being prone to interdisciplinarity, but the field rarely goes for it. A focus on order, combined with these arguments, may well shed light on how people in the region reproduce and uphold (as well as challenge and reframe) the workings of specific norms, principles, and institutions; it may also contribute to defining and negotiating intersections between national and regional forms of identity, neighborliness, and togetherness. This research

Ikboljon Qoraboyev, "From Regional Integration to Soft Institutionalism: What Kind of Regionalism for Central Asia?” in Integration Processes and State Interests in Eurasia, ed. Jildiz Nicharapova and Sebastien Peyrouse, conference proceedings of annual international conference American University of Central Asia (Bishkek, June 11, 2018), 83-97, available at https://research.auca.kg/wp-content/uploads/sites/21/2017/10/Integration -Processes-and-State-Interests-in-Eurasia.pdf.

83 For an overview, see Amitav Acharya, "Global International Relations (IR) and Regional Worlds," International Studies Quarterly 58, no. 4 (2014): 647-659, https://doi.org/10.111/ isqu.12171; and Giovanni Barbieri, "Regionalism, Globalism and Complexity: A Stimulus Towards Global IR?” Third World Thematics: A TWQ Journal 4, no. 6 (2019): 424-441.

84 Barry Buzan and Laust Schouenborg, Global International Society-A New Framework of Analysis (Cambridge: Cambridge University Press, 2019). 
trajectory would have the merit of moving the conception of order outlined in this paper from a state-centric perspective to a human, society-based one.

Second, given that Central Asian order does not exist in a vacuum but insists on a wider substratum of rules and norms linking all states together, studies suggesting that the legitimacy of international institutions should always be studied and contextualized in the regional context may show that understanding the norms, goals, and principles of Central Asian order is pivotal if meaningful cooperation is to be fostered between Western international organizations and Central Asian governments, as it is through processes of contextualization and localization that the international can work in and with the local. ${ }^{85}$

Third-and once again venturing into interdisciplinary terrain-scholars should conduct more research on whether local and precolonial understandings of social order and collective management of the political space (the region) are to be found in the discourse and practices of state representatives and of those non-state actors involved in the replication of order-making actions. ${ }^{86}$ This would require a much-needed process of epistemic decolonization and an uncovering of local agency and meaning-making, for example, by relying more on the work of scholars from the region and on more grounded context-embeddedness. From an epistemological perspective, this would imply a move from positivism to interpretivism and thick-descriptive approaches to the politics of the region to uncover and make intelligible the meaning and purpose of local discourses and practices. This would allow us to gain a more genuine and authentic understanding of how local interpretations and contestations of liberal principles of political organization feed back into weakening logics of the international liberal order, perhaps providing a sharper account of how Central Asia may find its way in a global framework of international relations.

85 Alexander Cooley, Great Games, Local Rules (New York: Oxford University Press, 2012); see also Assylzat Karabayeva, "Leaders, Ideas, and Norm Diffusion in Central Asia and Beyond," Asian Journal of Comparative Politics (December 6, 2019).

86 Timur Dadabayev and John Heathershaw, "Central Asia: A Decolonial Perspective on Peaceful Change," in The Oxford Handbook of Peaceful Change in International Relations, ed. T.V. Paul et al. (Oxford: Oxford University Press, 2020). 